\title{
PROFIL PIODERMA PADA ANAK DI POLIKLINIK KULIT DAN KELAMINRSUP PROF. DR. R. D. KANDOU MANADO PERIODE JANUARI-DESEMBER 2012
}

\author{
${ }^{1}$ Caren C.a Pangow \\ ${ }^{2}$ Herry E. J. Pandaleke \\ ${ }^{2}$ Renate T. Kandou \\ ${ }^{1}$ Kandidat skripsi Fakultas Kedokteran Universitas Sam Ratulangi Manado, \\ ${ }^{2}$ Bagian/SMF Kulit dan Kelamin RSUP Prof. Dr. R. D. Kandou Manado \\ Email: cpangow_11_056@yahoo.co.id
}

\begin{abstract}
Pyoderma is a skin infection caused byeither or both of staphylococcus and streptococcus bacteria. This infectious skin diseases are still the main problem of high level morbidity cases in children, especially indeveloping countries with topical climate including Indonesia. This study's goal to gain pyoderma patients profile in children at the dermatovenereology clinic of Prof. Dr R. D. Kandou General Hospital Manado during the period from January - December 2012. This is a retrospectivedescriptive study from the secondary data of pyoderma'spatient in children, based on the number of patients, sex, age, diagnose, nutritional status, and therapy. The results showed that of pyoderma's cases in children during January - Decemberwas fifty three cases (16,51\%). The distribution based on sex mostly on female (56,6\%), based on age infected group mostly on 1-4 years old $(43,4 \%)$. The majortypes of pyoderma isimpetigo (58,5\%). The distributionbased on nutritional status mostly on well-nourished (64,7\%). There were thirty fivepatients (66\%) givensystemic antibiotic with topical therapy.The most systemic antibiotics therapy used was erythromycin (62,2\%), and the most topical therapy used was fusidic acid (34 \%).
\end{abstract}

Keywords: pyoderma, children

\begin{abstract}
Abstrak: Pioderma adalah infeksi kulit yang disebabkan oleh kuman staphylococcus, streptococcus atau keduanya.Penyakit infeksi kulit masih merupakan masalah utama penyebab tingginya angka morbiditas pada anak-anak terutama di negara-negara berkembang dan wilayah beriklim tropis, termasuk di Indonesia.Tujuan penelitian ini untuk mengetahui profil pasien pioderma pada anak di Poliklinik Kulit dan Kelamin RSUP Prof. Dr. R. D. Kandou Manado periode Januari 2012 - Desember 2012. Penelitian ini merupakan penelitian deskriptif retrospektif dari data sekunder pasien pioderma anak (umur 0-14 tahun) berdasarkan jumlah pasien, umur, jenis kelamin, diagnosis, status gizi, dan terapi. Hasil penelitian menunjukkan bahwa pioderma pada anak periode januari - desember 2012 sebanyak 53 kasus (16,51\%). Distribusi menurut jenis kelamin terbanyak pada perempuan (35,6 \%) dan menurut umur terbanyak adalah kelompok umur 1-4 tahun (43,4\%). Jenis pioderma terbanyak adalah impetigo (58,5\%). Distribusi menurut status gizi terbanyak adalah bergizi baik $(64,7 \%)$. Sebanyak 35 pasien (66\%) diberikan terapi antibiotik sistemik dengan topikal. Terapi antibiotik sistemik terbanyak yang digunakan adalah eritromisin (62,2\%), dan topikal yang paling sering digunakan adalah asam fusidat (34\%).
\end{abstract}

Kata kunci: pioderma, anak 
Penyakit infeksi kulit masih merupakan masalah utama penyebab tingginya angka morbiditas pada anak-anak terutama di negara-negara berkembang dan wilayah beriklim tropis. ${ }^{1}$ Penyakit infeksi ini sering di jumpai pada anak karena daya tahan kulit terhadap invasi kuman patogen belum sesempurna orang dewasa. ${ }^{2}$ Sebanyak 18 studi prevalensi populasi umum di Negara berkembang melaporkan prevalensi yang tinggi untuk penyakit infeksi kulit (2187\%). Gangguan yang paling umum pada anak adalah pioderma $(0,2-35 \%)$ di ikuti dengan tinea kapitis (1-19,7\%), skabies $(0,2-24 \%)$, dan gangguan kulit akibat virus $(0,4-9 \%){ }^{3}$

Pioderma merupakan suatu infeksi bakteri kulit yang sering di derita anakanak. Pioderma adalah infeksi kulit yang disebabkan oleh kuman staphylococcus aureus dan streptococcus. Dari 18 penelitian bakteriologi menunjukan bahwa streptococcus group A merupakan etiologi utama pioderma di banyak Negara berkembang tropis diikuti staphylococcus aureus. $^{3}$

Data dari Kelompok Studi Dermatologi Anak Indonesia (KSDAI) yang dikumpulkan dari 8 Rumah Sakit di Indonesia tahun 2011, pioderma pada anak menempati urutan pertama. Pada studi tersebut didapatkan 13,86\% dari 8.919 kunjungan baru pasien kulit anak adalah pioderma. $^{4}$

Di Manado sendiri dari data yang dilaporkan di poliklinik RSUP Prof. Dr. R.D. Kandou tahun 2006- 2008 terdapat 571 pasien anak (42,26\%) dengan penyakit kulit infeksi dari total 1351 kunjungan pasien. dan penelitian tahun 2009-2011 terdapat 272 anak penderita infeksi kulit dari total 595 kunjungan dan pioderma diketahui merupakan infeksi kulit yang paling sering dengan jumlah kasus 151 $(55,51 \%)$ disusul infeksi virus 59 (21,69\%), jamur $43(15,81 \%)$ dan parasit $19(6,99 \%)$. $^{5,6}$

Hampir semua anak pernah mengalami infeksi kulit. Terjadinya infeksi kulit terutama pioderma mempunyai hubungan erat dengan beberapa faktor predisposisi antara lain higiene perorangan yang buruk dan sanitasi lingkungan yang kurang, gizi di hubungkan dengan berat badan serta aktifitas fisik anak sehari-hari, kondisi imunologis menurunnya daya tahan karena kurang gizi, anemia, penyakit keganasan, penyakit menahun, diabetes mellitus, dan telah adanya penyakit lain di kulit sehingga fungsi kulit terganggu dan memudahkan terjadi infeksi. ${ }^{7,8,9}$

Pioderma pada anak masih menjadi permasalahan di negara-negara berkembang termasuk Indonesia, khususnya di kota Manado. Masih cukup banyak insiden angka kesakitan pioderma pada anak, sehingga diperlukan adanya evaluasi perkembangan penyakit ini di poliklinik kulit dan kelamin RSUP. Prof Dr. R.D. Kandou Manado periode Januari-Desember 2012.

\section{METODOLOGI PENELITIAN}

Penelitian ini bersifat deskriptif retrospektif dengan mengambil data sesuai buku register di Poliklinik Kulit dan Kelamin, disesuaikan dengan catatan rekam medik pasien di Instalasi Rekam Medik RSUP Prof. Dr. R. D. Kandou Manado. Populasi penelitian mencakup semua data pasien baru yang berobat di poliklinik RSUP Prof. Dr. R. D. Kandou Manado periode januari - desember 2012 dan sampel penelitian yaitu semua psien baru yang terdiagnosa dengan pioderma pada usia 0 - 14 tahun. Variabel penelitian yaitu umur, jenis kelamin, diagnosa pioderma, status gizi, dan terapi.

\section{HASIL PENELITIAN}

Berdasarkan penelitian deskriptif retrospektif mengenai pioderma pada anak di bagian Poliklinik Kulit dan Kelamin dan Istalasi Rekam Medik RSUP Prof. Dr. R.D. Kandou Manado periode januari sampai desember 2012 maka diperoleh data berdasarkan variabel, yaitu sebagai berikut:

Berdasarkan distribusi diatas didapatkan jumlah keseluruhan pasien yang berobat adalah sebesar 4023 pasien dan 31,84 \% diantaranya adalah pasien anak (Tabel 1). 
Pada tabel 2 dapat dilihat jumlah pasien anak dengan pioderma berjumlah 53 kasus (16,51\%) dari total 321 kunjungan pasien anak.

Tabel 1. Distribusi kunjungan pasien anak

\begin{tabular}{l|l|l}
\hline Tahun & $\begin{array}{l}\text { Total } \\
\text { kunjungan } \\
\text { keseluruhan } \\
\text { pasien }\end{array}$ & $\begin{array}{l}\text { Total } \\
\text { kunjungan } \\
\text { pasien anak }\end{array}$ \\
\hline 2012 & 4023 & $321(7,97 \%)$ \\
\hline
\end{tabular}

Tabel 2. Distribusi kunjungan pasien pioderma anak.

\begin{tabular}{l|l|l}
\hline Tahun & $\begin{array}{l}\text { Total kunjungan } \\
\text { keseluruhan } \\
\text { pasien anak }\end{array}$ & $\begin{array}{l}\text { Total } \\
\text { kunjungan } \\
\text { pasien } \\
\text { pioderma } \\
\text { pada anak }\end{array}$ \\
\hline 2012 & 321 & $53(16,51 \%)$ \\
\hline
\end{tabular}

Berdasarkan distribusi umur pasien pioderma pada anak diatas didapatkan bahwa usia terbanyak yaitu pada golongan umur 1-4 tahun sebanyak 23 pasien (43,4\%) (Tabel 3).

Tabel 3. Distribusi umur pasien

\begin{tabular}{lll}
\hline Umur & $\begin{array}{l}\text { Jumlah } \\
\text { pasien }\end{array}$ & $\begin{array}{l}\text { Persentasi } \\
\mathbf{( \% )}\end{array}$ \\
\hline$<1$ tahun & 12 & $22,6 \%$ \\
1-4 tahun & 23 & $43,4 \%$ \\
5-14 tahun & 18 & $34,0 \%$ \\
\hline Total & $\mathbf{5 3}$ & $\mathbf{1 0 0} \%$ \\
\hline
\end{tabular}

Berdasarkan distribusi jenis kelamin pasien pioderma diatas didapatkan bahwa jenis kelamin penderita pioderma terbanyak pada perempuan yaitu 30 (56,6\%) (Tabel 4).

Tabel 4. Distribusi jenis kelamin

\begin{tabular}{lll}
\hline $\begin{array}{l}\text { Jenis } \\
\text { kelamin }\end{array}$ & $\begin{array}{l}\text { Jumlah } \\
\text { pasien }\end{array}$ & $\begin{array}{l}\text { Persentasi } \\
(\mathbf{\% )}\end{array}$ \\
\hline Laki-laki & 23 & $43,4 \%$ \\
Perempuan & 30 & $56,6 \%$ \\
\hline Total & $\mathbf{5 3}$ & $\mathbf{1 0 0 \%}$ \\
\hline
\end{tabular}

Berdasarkan distribusi jenis pioderma pada anak diatas didapatkan bahwa jenis pioderma pada anak yang paling sering ialah impetigo dengan jumlah kasus 31
(58,5\%) (Tabel 5)

Tabel 5. Distribusi jenis diagnosis pioderma.

\begin{tabular}{lll}
\hline Diagnosis & $\begin{array}{l}\text { Jumlah } \\
\text { pasien }\end{array}$ & $\begin{array}{l}\text { Persentasi } \\
(\mathbf{\%})\end{array}$ \\
\hline Impetigo & 31 & $58,5 \%$ \\
Ektima & 1 & $1,9 \%$ \\
Folikulitis & 7 & $13,2 \%$ \\
Furunkel & 11 & $20,8 \%$ \\
Karbunkel & 2 & $3,8 \%$ \\
Erisipelas & 0 & $0 \%$ \\
Selulitis & 1 & $1,9 \%$ \\
\hline Total & $\mathbf{5 3}$ & $\mathbf{1 0 0} \%$ \\
\hline
\end{tabular}

Berdasarkan distribusi jenis pioderma diagnosis impetigo pada anak diatas didapatkan bahwa jenis impetigo pada anak yang terbamyak ialah impetigo bulosa dengan jumlah kasus 16 (30,2\%) (Tabel 6).

Tabel 6. Distribusi jenis pioderma diagnosis impetigo pada anak

\begin{tabular}{lll}
\hline Diagnosis & $\begin{array}{l}\text { Jumlah } \\
\text { pasien }\end{array}$ & $\begin{array}{l}\text { Persentasi } \\
(\mathbf{\%})\end{array}$ \\
\hline Impetigo krustosa & 15 & $28,3 \%$ \\
Impetigo bulosa & 16 & $30,2 \%$ \\
\hline Total & $\mathbf{3 1}$ & $\mathbf{5 8 , 5} \%$ \\
\hline
\end{tabular}

Berdasarkan distribusi status gizi dari 17 data pasien pioderma anak yang ada didapatkan bahwa status gizi anak yang terbamyak ialah berststus gizi baik dengan jumlah 11 anak (64,7\%) (Tabel 7).

Tabel 7. Distribusi status gizi

\begin{tabular}{lll}
\hline Status Gizi & $\begin{array}{l}\text { Jumlah } \\
\text { pasien }\end{array}$ & $\begin{array}{l}\text { Persentasi } \\
\mathbf{( \% )}\end{array}$ \\
\hline Obesitas & - & $0 \%$ \\
Gizi Lebih & 1 & $5,9 \%$ \\
Baik & 11 & $64,7 \%$ \\
Gizi kurang & 4 & $23,5 \%$ \\
Gizi buruk & 1 & $5,9 \%$ \\
\hline Total & $\mathbf{1 7}$ & $\mathbf{1 0 0 \%}$ \\
\hline
\end{tabular}

Berdasarkan distribusi terapi pasien pioderma anak diatas didapatkan bahwa terapi yang terbamyak digunakan ialah terapi kombinasi antara antibiotik sistemik dan topikal yaitu sebanyak 35 (66\%) (Tabel 7).

Berdasarkan distribusi terapi dengan antibiotik sistemik pasien pioderma anak 
diatas didapatkan bahwa terapi antibiotik sistemik yang sering digunakan ialah antibiotik golongan eritromisin, yaitu sebanyak 28 (62,2\%) (Tabel 8).

Tabel 7. Distribusi terapi

\begin{tabular}{lll}
\hline Terapi & $\begin{array}{l}\text { Jumlah } \\
\text { pasien }\end{array}$ & $\begin{array}{l}\text { Persentasi } \\
\mathbf{( \% )}\end{array}$ \\
\hline Antibiotik & 3 & $5,7 \%$ \\
sistemik (AS) & & \\
Topikal & 15 & $28,3 \%$ \\
AS+topikal & 35 & $66 \%$ \\
\hline Total & $\mathbf{5 3}$ & $\mathbf{1 0 0} \%$ \\
\hline
\end{tabular}

Tabel 8. Distribusi jenis terapi antibiotik sistemik

\begin{tabular}{lll}
\hline Terapi & $\begin{array}{l}\text { Jumlah } \\
\text { pasien }\end{array}$ & $\begin{array}{l}\text { Persentasi } \\
(\mathbf{\% )}\end{array}$ \\
\hline Eritromisin & 28 & $62,2 \%$ \\
Amoksisilin & 8 & $17,8 \%$ \\
Cefadroxcyl & 7 & $15,6 \%$ \\
Cefixime & 2 & $4,4 \%$ \\
\hline Total & $\mathbf{4 5}$ & $\mathbf{1 0 0} \%$ \\
\hline
\end{tabular}

Berdasarkan distribusi terapi dengan antibiotik topikal pasien pioderma anak diatas didapatkan bahwa terapi antibiotik topikal yang sering digunakan ialah antibiotik topikal $\mathrm{Na}$ Fusidat, yaitu sebanyak 17 (34\%) (Tabel 9).

Tabel 9. Distribusi jenis terapi topikal

\begin{tabular}{|c|c|c|c|}
\hline \multicolumn{2}{|c|}{ Pengobatan } & $\begin{array}{l}\text { Jumlah } \\
\text { pasien }\end{array}$ & $\begin{array}{l}\text { Persentasi } \\
(\%)\end{array}$ \\
\hline Mupirocin & & 9 & $18 \%$ \\
\hline Gentamisin & & 7 & $14 \%$ \\
\hline Na Fusidat & & 17 & $34 \%$ \\
\hline $\begin{array}{l}\text { Kompres } \\
0,9 \%\end{array}$ & $\mathrm{NaCl}$ & 5 & $10 \%$ \\
\hline $\begin{array}{l}\text { Kompres } \\
0,9 \%\end{array}$ & $\begin{array}{r}\mathrm{NaCl} \\
+\end{array}$ & 4 & $8 \%$ \\
\hline $\begin{array}{l}\text { Mupirocin } \\
\text { Kompres } \\
0,9 \% \\
\text { Gentamisin }\end{array}$ & $\begin{array}{r}\mathrm{NaCl} \\
+\end{array}$ & 1 & $2 \%$ \\
\hline $\begin{array}{l}\text { Kompres } \\
0,9 \% \quad+ \\
\text { Fusidat }\end{array}$ & $\begin{array}{r}\mathrm{NaCl} \\
\mathrm{Na}\end{array}$ & 7 & $14 \%$ \\
\hline Total & & 50 & $100 \%$ \\
\hline
\end{tabular}

\section{BAHASAN}

Pada penelitian ini, sampel yang diambil ialah seluruh pasien kasus baru pioderma pada anak yang berobat di poliklinik RSUP Prof. DR. R.D. Kandou Manado periode Januari sampai Desember 2012.

Seperti terlihat pada tabel 1 total kunjungan pasien baru di poliklinik kulit dan kelamin RSUP.Prof.Dr.R.D. Kandou Manado periode Januari sampai Desember tahun 2012 adalah 4023 pasien dan 31,84\% adalah kunjungan dari pasien anak.

Berdasarkan data yang ada, jumlah pasien anak adalah 321 kunjungan dan pasien anak dengan diagnosis pioderma ada 53 pasien atau sekitar 16,51\%. Pada Penelitian sebelumnya tahun 2006-2008 di RSUP Prof. Dr. R. D. Kandou Manado di divisi Dermatologi anak terdapat 90 pasien (2006), 117 pasien (2007), dan 58 pasien (2008) dan penelitian yang sama oleh peneliti berbeda pada tahun 2009-2011 terdapat 151 total kasus pioderma pada anak. ini membuktikan bahwa insidens pioderma masih cukup tinggi. ${ }^{6,7}$

Dari data distribusi menurut umur menunjukkan bahwa usia 1-4 tahun yang paling banyak mengalami pioderma, yaitu sekitar 43,4\% diikuti kelompok umur 5-14 tahun dan kelompok umur $<1$ tahun. Pada penelitian yang dilakukan di RSU Dr. Soetomo Surabaya periode 2008-2010juga didapatkan usia yang paling sering adalah kelompok umur 1-4 tahun. Pada anak yang berusia lebih tua dan kelompok umur usia pra-sekolah juga sekolah memiliki faktor predisposisi yang memudahkan mereka terkena pioderma. Anak-anak tersebut mulai mengenal lingkungan dan bereksplorasi dengan alam sekitar. Kebiasan bermain berkelompok dan jenis permainan, dapat mempermudah masuknya bakteri patogen ditambah lagi hygiene dan sanitasi yang kurang turut memperburuk keaadaan kulit pada anak. ${ }^{10,11}$

Dari data distribusi menurut jenis kelamin memperlihatkan perempuan lebih banyak menderita pioderma dibandingkan laki-laki, namun hasilnya tidak menunjukkan perbedaan yang signifikan. Perempuan dengan 56,6\% sedangkan lakilaki dengan 43,4\%. Penelitian retrospektif yang dilakukan di RS Sanglah Denpasar 
periode januari 2006 sampai Desember 2008 didapatkan penderita laki-laki lebih lebih banyak daripada perempuan dengan perbandingan yang juga tidak signifikan, yaitu laki-laki 56,6 \% dan perempuan 43,4 \%. Dapat dilihat bahwa infeksi pioderma dapat terjadi pada laki-laki dan perempuan. $^{11}$

Pada tabel 5 didapatkan bahwa jenis diagnosis pioderma terbanyak berturutturut adalah impetigo dengan 31 pasien (58,5\%), furunkel dengan 11 pasien (20,8\%) folikulitis dengan 7 pasien (13,2\%), karbunkel dengan 2 pasien (3,8\%), untuk ektima dan selulitis masingmasing 1 pasien (1,9\%) tapi erysipelas tidak terdapat kasus. Hal yang sama juga dilaporkan pada penelitian Harahap J, di RSUP Prof. Dr. R. D. Kandou Manado tahun 2009-2011 impetigo adalah yang terbanyak. Penelitian di RS lain juga didaptkan bahwa impetigo adalah yang paling banyak dijumpai, di RS Soetomo Surabaya impetigo ditemukan 40,5\% dan di Sanglah Denpasar impetigo ditemukan $37,7 \%$. $^{7,11,12}$

Impetigo merupakan pioderma yang tersering pada anak-anak. Pada tabel 4a ditemukan jenis impetigo yang paling banyak adalah impetigo bulosa yaitu 16 pasien, namun perbandingan dengan data yang ditemukan untuk kasus impetigo krustosa tidak terdapat perbedaan yang besar karena pada impetigo krustosa juga didapatkan 15 pasien. Pada penelitian yang dilaporkan oleh pandeleke H.E.J dan Warouw F.T.H di RS Gunung Wenang Manado (1989-1991), Hehanussa A di RSU Prof. Dr. R.D. Kandou Manado (20012005), Setiawan S di RSU Prof. Dr. R.D. Kandou Manado (2005-2006) dan Harahap J juga RSU Prof. Dr. R.D. Kandou Manado (2009-2011) impetigo krustosa yang paling banyak ditemukan. Ini menunjukkan bahwa kasus impetigo bulosa juga sudah cukup meningkat. ${ }^{6,7}$

Salah satu faktor predisposisi terjadinya pioderma adalah karena gizi kurang, pada penelitian ini diteliti mengenai status gizi dari pasien pioderma anak, namun dari 53 pasien anak yang tercatat pioderma hanya didapatkan 17 data mengenai berat badan untuk di analisis status gizinya. Pada tabel 7 dari 17 data tersebut ditemukan bahwa 1 anak berstatus gizi lebih. 11 anak dengan status gizi baik, 4 anak dengan status gizi kurang dan 1 anak dengan ststus gizi buruk dan tidak didapatkan pasien pioderma yang obesitas. Selain faktor gizi faktor predisposisi yang sangat berkaitan dengan terjadinya pioderma juga adalah kebersihan anak yang buruk, kesehatan yang buruk dan sistem kekebalan tubuh anak yang lemah, serta faktor yang dapat meningkatkan resiko penyakit ini adalah iritasi tekanan, gesekan dan garukan pada kulit anak. ${ }^{13}$

Pada tabel 7 dapat dilihat data mengenai distribusi terapi yang diberian di poliklinik RSU Prof. Dr. R.D. Kandou Manado periode Januari sampai Desember 2012 pada pasien pioderma anak. dari hasil tersebut dapat disimpulkan bahwa penggunaan obat untuk terapi pioderma yang paling sering diberikan adalah terapi kombinasi antara antibiotik sistemik dan topikal. Pemberian terapi tersebut juga berdasarkan diagnosis jenis pioderma yang diderita pasien anak.

Dari pemberian terapi antibiotik sistemik, pada tabel 8 didapatkan bahwa antibiotik golongan eritromisin adalah antibiotik yang paling sering digunakan yaitu, sekitar 28 pasien (62.2\%) diikuti pemberian antibiotika cefadroxil, amoksisilin, dan cefixim. Penelitian oleh Dewi D.K di RSU Dr. Soetomo Surabaya tahun 2002-2006 juga didapatkan hasil bahwa antibiotik yang paling sering digunakan adalah eritromisin. Eritromisin larut lebih baik dalam etanol dan pelarut organik sehingga cepat terdifusi dengan baik. Untuk terapi topikal, dari hasil yang ada dapat dilihat pada tabel 9 bahwa topikal yang paling sering digunakan adalah pembeian antibiotik $\mathrm{Na}$ Fusidat yaitu sebanyak 17 pasien, diikuti Mupirocin 9 pasien, Gentamisin 7 pasien, kombinasi kompres $\mathrm{NaCl}$ 0.9\% dengan $\mathrm{Na}$ Fusidat pada 7 pasien, $\mathrm{NaCl} 0,9 \%$ saja pada 5 pasien, kombinasi kompres $\mathrm{NaCl}$ 0,9\% dengan Mupirocin 4 pasien dan kombinasi 
kompres $\mathrm{NaCl}$ 0.9\% dengan gentamisin pada 1 pasien anak. ${ }^{12}$

\section{SIMPULAN}

Dari penelitian mengenai pioderma pada anak di RSU Prof. Dr. R.D. Kandou Manado periode januari sampai desember 2012, dapat disimpulkan jumlah pasien kasus baru pioderma pada anak sebanyak 53 kasus, dengan terbanyak kelompok umur 1-4 tahun, jenis kelamin perempuan, diagnosis impetigo, impetigo bulosa adalah jenis impetigo yang paling banyak, 17 data dari 53 data yang ada mengenai status gizi pasien pioderma anak berstatus gizi baik, terapi yang paling sering diberikan adalah pemberian terapi kombinasi antara antibiotik sistemik dengan topikal, antibiotik sistemik tersering digunakan golongan eritromisin dan topikal yang paling sering diberikan adalah $\mathrm{Na}$ Fusidat.

\section{SARAN}

Kelengkapan dalam pengisian status pasien sangat diperlukan guna menunjang pendataan yang lengkap, akurat dan informatif. Pengumpulan dan penyimpanan catatan rekam medikjuga harus diperhatikan. Perlu ditingkatkan tindakan kuratif dan preventif untuk pasien pioderma dan keluarga agar mencegah faktor predisposisi, membatasi sumber infeksi dan mencegah penularan. Dan juga perlu adanya penelitian lebih lanjut dan lebih rinci agar dapat memberikan informasi mengenai perkembangan penyakit pioderma pada anak.

\section{DAFTAR PUSTAKA}

1. Resnick SD. Staphylococcal and Streptococcal skin infections: Pyodermas and toxin-mediated syndromes. In: Harper J, Oranje A, Prose N, editor. Textbook of pediatric dermatology. Edisi 2. Oxford: Blackwell ScienceLtd:2006 .p.455-8.

2. Abdoerrachman, M.H, dkk. Ilmu Kesehatan Anak 1. Edisi 11. Bagian Ilmu Kesehatan Fakultas Kedokteran Universita Indonesia. Jakarta. 2007.p. 247-9.
3. WHO. Epidemiology and Management of Common Skin Diseases in Children in Developing Countries. Jenewa: WHO.2005.p.v-vii. [cited on 2014 oct 7] available from:http://whqlibdoc.who.int/hq/2005/ WHO_FCH_CAH_05.12_eng.pdf.

4. KSDAI. Laporan catatan medis 8 RS di kota besar di Indonesia, 2001.

5. Setiawan S, Pandeleke HEJ. Pioderma primer di Divisi Dermatologi Anak unit rawat jalan kulit dan kelamin RSU Prof. Dr. R.D. Kandou Manado periode 2005-2006. In: Gaspersz S, Jackqueline S, Pandeleke HEJ, Kartini A. Penyakit kulit infeksi di divisi dermatologi anak poliklinik kesehatan kulit dan kelamin RSUP Prof. Dr.R.D Kandou Manado. Kumpulan naskah ilmiah PIT $\mathrm{X}$ PERDOSKI. 2009: 283-6.

6. Harahap J. Pola infeksi kulit pada anak di Poliklinik Kulit dan Kelamin RSUP. Prof. Dr. R.D Kandou Manado tahun 2009-2011.skripsi. Fakultas Kedokteran Unsrat.2013.

7. Benson MP, Hengge RU. Staphylococcal dan Streptococcal Pyodermas. In: trying KS, Lupi O, Hengge RU, editor. Tropical dermatology. Philadelphia: Elsevier Inc: 2006.p.241.

8. Heragandhi N. Kuman penyebab pioderma superfisialis pada anak, dan kepekaannya terhadap beberapa antibiotik. Tesis. Fakultas Kedokteran Universitas Indonesia.2004

9. Boediardjo SA. Epidemiologi penyakit infeksi serta peran sawar kulit pada infeksi mikroorganisme pada kulit bayi dan anak. Dalam: Boediardja SA, Sugito TL, Kerniati DD, Elandari, editor. Infeksi kulit pada bayi dan anak. Jakarta: Balai penerbit FK UI: 2003.p.3-5.

10.Rahmawati A. Pioderma superfisialis primer pada anak di unit rawat jalan kesehatan kulit \& kelamin RSUD Dr. Soetomo Surabaya periode 2008-2010. Berkala 2012; 24: 7-13.

\section{BAAA Laksmi Dewi, IPK Dhana Saputra,LM Rusyanti, Md Bratiartha, MS Adiguna,. Profil Pioderma diPoliklinik Kulit dan Kelamin RS Sanglah Denpasar periode Januari 2006-Desember 2008. Kumpulan naskah ilmiah PIT X}


Jurnal e-Clinic (eCl), Volume 3, Nomor 1, Januari-April 2015

PERDOSKI. 2009: 12-14.

12.Dewi D.K, Rosvanti A, Andriyani C. Penelitian retrospektif pioderma pada anak di Instalasi Rawat Inap Kesehatan Kulit dan Kelamin RSUD Dr. Soetomo
Surabaya.2006.

13.Sjahrial. Infeksi bakteri stafilokok dan streptokok. Dalam: Harahap M. Infeksi Penyakit Kulit. I. hipokrates.2000.p.4658. 